Araştırma makalesi

\title{
Denizcilik eğitiminde kullanılan simülatörlerin dünya çapında dağılımı
}

Firat Bolat ${ }^{1 *}$

${ }^{1}$ İstanbul Teknik Üniversitesi Denizcilik Fakültesi Gemi Makineleri İşletme Mühendisliği Bölümü, Tuzla, İstanbul, Türkiye

*Correspondence: bolatf@itu.edu.tr

DOI:10.51513/jitsa.871903

Özet: Tarih boyunca, denizcilik eğitiminde deniz simülasyonu, dünyanın dört bir yanındaki gemilere nitelikli, iyi eğitilmiş, işinin ve çevresinin sorumluluğunu taşıyabilen kaptanlar ve mühendisler yetiştirmek için kullanılmıştır. Simülasyonlar gerçek ortamları sanal gerçeklikle ve minimum risk oluşturarak kullanıcıya sunarlar. Özellikle denizcilik sektörü gibi gerçek yük operasyonlarında, seyirde, makine dairesinde, güvertede en ufak bir hatada yüksek maliyetlerin ve hatta can kayıplarının olabileceği risklerin mevcut olduğu bir alanda eğitimin en gerçekçi ve risksiz bir şekilde gerçekleştirilmesi büyük önem taşımaktadır. Denizcilikte birçok dünya ülkesi simülatörlerin kullanıldığı eğitimin çok etkili, verimli ve güvenli olduğunu yaygın bir şekilde belirtmişlerdir. Ancak dünya üzerindeki her kurum, kapsamlı eğitim programına her zaman sorunsuz bir şekilde uymayan kendi simülatör tabanlı eğitim kursunu ve programını geliştirmiştir. Bu amaçla, bu çalışmada tüm dünyadaki simülatör tesislerinin bulunduğu ülke ve şehirler araştırılmıştır. Simülatör tesislerinin, ülke ve lokasyona göre anlamlı bir farklılık oluşturup oluşturmadığı tespit edilmiş, buna göre anlamlı kümelerin oluşturulup oluş̧urulamayacağı incelenmiştir. Analiz sonucuna göre anlamlı kümeler oluşmuş, her bir kümede yer alan ülke ve şehirler saptanmıştır. Analiz sonuçlarından elde edilen kümelerdeki ülke ve şehirlerin denizcilikle alakalı üniversitelerinde yer alan simülatör tiplerine göre eğitim biçiminin ve yetkinliklerinin incelenmesi için elde edilen bu öncü dünya ülkelerinin ve şehirlerinin referans oluşturması amaçlanmıştır.

Anahtar Kelimeler: Simülatör tesisi, Denizcilik, Kümeleme analizi

\section{Distribution of simulators used in maritime education around the world}

\begin{abstract}
Throughout history, marine simulation in maritime education has been used to train qualified, well-trained captains and engineers who can take responsibility for their job and environment to ships around the world. Simulations present real environments to the user with virtual reality and with minimal risk. It is great importance that the training is carried out in the most realistic and risk-free way in an area where there are risks in which there may be high costs and even loss of life in the slightest error on the navigation, engine room, deck, cargo operation in maritime. Many countries of the world in maritime have widely stated that the training using simulators is very effective, efficient and safe. However, every institution in the world has developed its own simulator-based training course and program, which does not always fit seamlessly into the comprehensive training program. For this purpose, the countries and cities where simulator facilities are located all over the world were researched in this study. It was determined whether the simulator facilities create a significant difference according to the country and location, and it was examined whether meaningful clusters could be created accordingly. According to the results of the analysis, meaningful clusters were formed and the countries and cities in each cluster were determined. It is aimed that these pioneering countries and cities of the world obtained from the analysis results to examine the training style and competencies according to the simulator types in the maritime related universities of the countries and cities in the clusters.
\end{abstract}

Key words: Simulator facility, Maritime, Clustering analysis

\footnotetext{
* Corresponding author. Tel.: 02163954501

E-mail address: bolatf@itu.edu.tr

ORCID: 0000-0001-9807-7089

Received 31 January 2021; accepted 09 March 2021

Peer review under responsibility of Bandirma Onyedi Eylul University.
} 


\section{Giriş}

Deniz simülatörleri, yetkin gemi adamları yetiştirmek için denizcilik eğitiminde teorik bilgiyi pratiğe çevirmede kullanılan önemli uygulamalı tesislerden biridir. Profesyonel denizciler yetiştirmek aynı zamanda denizcilik eğitimi alanında başarının ve rekabet gücünün de eksenini oluşturmaktadır. Denizcilik eğitim sürecinin yükseköğretim seviyelerinin niteliksel olarak yükseltilmesi, ağırlıklı olarak eğitmenlere, eğitim yazılımlarının öğretici değerlerine ve bunların aktarılmasına, uygulanmasına ve aktarılması için etkili eğitim sağlamada olumlu fayda sağlayan gelişmiş ve akıllı senaryolar içeren simülasyon programların içeriğine bağlıdır.

Simülasyonlar, gerçek platformlar, alanlar ve çevreler gibi dünya sistemlerini uygun teknolojik altyapısı ile sanal olarak benzetir, sistem maddeleri arasında ilişkiler kurar ve süreci modeller. Bu bağlamda sistem kullanıcısı yetkinlik kazanmak istediği alanda herhangi bir risk almadan en üst seviyede uygulama yapma imkânı bulur (Sendi, 2015). Özellikle, denizcilik sektöründe yer alan gemi, bünyesinde, yüksek riskli operasyonlar, bakımlar ve faaliyetler barındırır. Seyir, yük ve balast operasyonları, yakıt operasyonları, güverte ve makine bakım tutup faaliyetleri gibi süreçlerde sorumlu olacak gemi adamlarının ilgili konularda yetkinlik kazanması için verilen eğitimin minimum risk ve maksimum gerçeklik ile gerçekleşmesi önem taşımaktadır. $\mathrm{Bu}$ amaçla denizde öngörülemeyen olaylardan kaçınmak için risksiz bir ortamda beceri kazandırmak büyük bir avantaj sağlamaktadır.

Uluslararas1 Denizcilik Örgütü (IMO), simülatörler için teknik standartları geliştirmek için denizcilik topluluğunu kurmuştur (Cross, 2011). İçerisinde Uluslararası Deniz Simülatörü Forumu (IMSF), Uluslararası Denizcilik Eğitmenleri Birliği (IMLA), Det Norske Veritas (DNV) gibi önemli denizcilik organizasyon ve klas kuruluşlarının yer aldığı topluluk simülasyon sınıflarını oluşturmuştur (Board, 1996). Buna göre deniz simülatörleri dört ana gruba göre sınıflandırılmıştır. Birinci kategori gelişmiş manevra yetenekleri olan ve pilot eğitimlerinin de verilebildiği Birleştirilmiş Köprü üstü Simülatörleri gibi bütün görevleri gerçekleştirebilen simülatörleri içerir. İkinci kategori, yalnızca görsel seyir ve gerçek zamanlı işletim yeteneklerini içeren ve çoklu görev olarak sınıflandırılan yetenekleri içeren simülatörleri kapsar. Üçüncü kategori, RADAR simülatörü gibi sınırlı görev olarak sinıflandırılan yetenekleri içeren simülatörlerdir. Dördüncü kategori ise, bilgisayar-temelli eğitim simülatörleri (CBT) gibi özel görevler olarak sinıflandırılan simülatörleri içerir (Board, 1996).

Denizcilik eğitiminde Gemi Adamlarının Eğitim, Belgelendirme ve Vardiya Tutma Standartları (STCW)'ye uygun olarak kullanılan çok çeşitli simülatör tipleri bulunmaktadır. Bunlardan bazıları, köprü üstü, makine, RADAR, Küresel Denizcilik Tehlike ve Güvenlik Sistemi (GMDSS) simülatörleri, bilgisayar temelli simülatörler, tanker simülatörleridir (Bouras, 2000).

Başta Japonya olmak üzere dünya çapında birçok denizcilik eğitim ve öğretim kurumu, modern mesleki gelişim teorisi ve uygulamaları ile kurulmuş profesyonel merkezlerdir. Denizcilikte ileri gitmiş birçok dünya ülkesi simülatörlerin kullanıldığı eğitimin çok etkili, verimli ve güvenli olduğunu yaygın bir şekilde belirtmişlerdir. 25 yıldan daha uzun bir süre boyunca, eğitim ve araştırma sonrası için uygun şekilde kullanıldığında ve anlaşıldığında güvenilir bir araç olduğu kanıtlanmıştır. Bununla birlikte, her kurum, kapsamlı eğitim programına her zaman sorunsuz bir şekilde uymayan kendi simülatör tabanlı eğitim kursunu ve programını geliştirmiştir. Eğitim etkinliğinin sadece simülatörler gibi ekipman yetenekleriyle değil, aynı zamanda eğitim metodolojisinin nasıl uygulandığıyla da artacağ 1 konusunda kabul görmüş fikirler vardır (Bouras, 2000).

Bir eğitim merkezinde eğitim için seçilecek simülatör tesisi önemlidir. Çünkü kurulan simülatör tesisine göre kilavuzların ve eğitmenlerin kullanımında olan tüm görev simülatörlerinin kullanımı ve bir simülatörün karmaşıklığına kadar tüm işleyiş değişebilir. Elde edilen simülatöre göre eğitim modülü, programı oluşur, öğretim tekniği gelişir, eğitim kurumunun yeterliliği belirlenir ve en önemlisi yetiştirilen denizci adaylarının yetkinlik seviyesi değişir.

$\mathrm{Bu}$ bağlamda, tüm dünyadaki simülatör tesislerinin bulunduğu ülke ve şehirler bu çalışma kapsamında araştırılmıştır. Simülatör 
tesislerinin, ülke ve lokasyona göre anlamlı bir farkl11ık oluşturup oluşturmadığ 1 tespit edilmiş, buna göre anlamlı kümelerin oluşturulup oluşturulamayacağı incelenmiştir. Analiz sonuçlarının dünya üzerindeki denizcilikle alakalı eğitim kurumlarında yer alan simülatör tiplerine göre eğitim biçiminin ve yetkinliklerinin incelenmesi için öncü dünya ülkelerinin ve şehirlerinin referans oluşturması amaçlanmıştır.

\section{Materyaller ve Yöntem}

$\mathrm{Bu}$ çalışmada denizcilik eğitim kurumları için tesis edilmiş simülatörlerin dünya üzerindeki dağılımları ülke ve şehir (lokasyon) bazlı olarak açıklayıcı istatistiki yöntemle gösterilmiştir. Çalışma için Küresel Entegre Denizcilik Bilgi Sistemi (GISIS) veri tabanı üzerinden toplanan verilerden dünya genelinde 674 adet simülatör olduğu tespit edilmiştir (Url-1). Bu simülatörler köprü üstü, makine ve diğer simülatörler olarak 3 ayrı grupta toplanmıştır. Diğer kategorisi, köprü üstü ve makine simülatörlerinden farklı olarak GMDSS, RADAR, ECDIS vb. simülatörleri içermektedir. Ayrıca hiyerarşik olmayan kümeleme yönteminde K-ortalamalar tekniği kullanılarak simülatörlerin ülkelere ve lokasyonlara göre anlamlı kümeler şeklinde dağılıp dağılmadığ incelenmiştir. Bu bağlamda yapılan analizlerin sonuçları 3. Bölüm Sonuçlar kısmında verilmiştir.

\subsection{Kümeleme Analizi, K-Ortalamalar Yöntemi}

Kümeleme analizi için en yaygın kullanılan yöntemler, hiyerarşik kümeleme analizi, hiyerarşik olmayan kümeleme analizi ve iki aşamalı kümeleme analizdir. K-ortalamalar tekniği ise hiyerarşik olmayan kümeleme yönteminde en çok kullanılan algoritmalarından biridir (Halkidi ve ark., 2001; Kanungo ve ark., 2002; Pakhira ve ark., 2004).

MacQueen (1967) ilk olarak K- ortalamalar algoritmasını literatüre katmıştır. Karmaşık ve büyük miktarlardaki verileri kullanarak anlamlı kümeler elde etmek için K-ortalamalar tekniği uygun bir yöntemdir. K-ortalamalar yöntemi, karmaşık bir veri kümesinden anlamlı olarak $\mathrm{k}$ adet grup oluşturur. Çalışma prensibine göre, başta $\mathrm{k}$ adet küme merkezi belirlenir. Her bir veri gözlemi mesafe olarak en yakın olduğu kümeye geçer. Ardından yeni üyeye sahip oluşan küme merkezi, her defasında sahip olduğu veri gözlemlerinin ortalamasını yeniden hesaplar ve ona uygun olarak diğer gözlemin mesafesi belirlenir. Her bir gözlemin kümeye olan uzaklığı Kareli Öklid denklemine göre hesaplanır. $\mathrm{Bu}$ aşamada aynı zamanda hata fonksiyonu tanımlanır. $\mathrm{Bu}$ aşamaların gerçekleştiği adımlar başlangıç adımı, tekrarlama adımı, iyileştirme adımı ve durma adımı olarak isimlendirilir (Wu ve Yang, 2002; Gan ve ark., 2007; Jain, 2010; Tekin, 2018).

\section{Analiz ve Bulgular}

674 adet simülatörün kategorilerine göre dağılımı Şekil 1'de gösterilmiştir. Buna göre dünya üzerinde 163 adet köprü üstü simülatörü ve 125 adet makine simülatörü bulunmaktadır. Geriye kalan 386 adet simülatör, GMDSS, ECDIS, RADAR vb. gibi diğer simülatör tiplerini içermektedir.

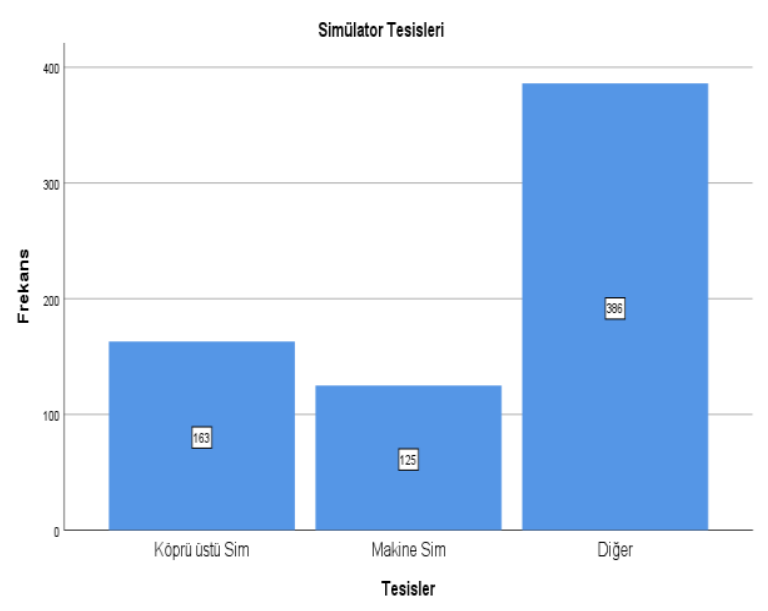

Şekil 1. Simülatörlerin kategorilerine göre
dağllımları.

Dünya üzerinde bulunan bu simülatörler 39 farklı ülke ve 103 farklı lokasyonda bulunmaktadır. Her bir ülkeye ve lokasyona ait simülatör sayılarının grafiksel gösterimleri Şekil 2, Şekil 3, Şekil 4 ve Şekil 5'deki gibidir.

Şekil 2'ye göre, 104 adet simülatör ile eğitim kurumlarında en fazla simülatörü olan ülke Polonya iken, ikinci sırada 62 adet simülatörü ile Türkiye gelmektedir. Endonezya 54, Fransa 53 adet simülatörü ile dünya da üçüncü ve dördüncü sırayı almaktadır. Dünya sıralamasında Polonya \% 15.4'lük dilime girerken, Türkiye \% 9.2, Endonezya $\% 8$ ve Fransa \% 7.9'luk dilimdedir. Diğer ülkelerin eğitim kurumlarındaki toplam simülatör sayısı ortalama 11 adet olup dünya sirlamasinda \% 3'lük dilimler şeklinde dağılım göstermektedir. 
Şekil 3'de simülatör tiplerinin ülkelere göre dağılımları gösterilmektedir. Özel olarak Polonya da bulunan 104 adet simülatörün, 21 tanesi köprü üstü simülatörü, 25 tanesi makine simülatörü ve 58 tanesi diğer simülatörlerden oluşmaktadır. Türkiye'de ise 14 tane köprü üstü simülatörü, 10 tane makine simülatörü ve 38 tane diğer simülatörler bulunmaktadır. Endonezya'da 12 şer adet makine ve köprü üstü simülatörü bulunurken, Fransa'da 15 adet köprü üstü, 13 adet makine simülatörü bulunmaktadır. Karş1laştırılan bu dört ülkeden en fazla köprü üstü ve makine simülatörüne sahip olan ülke Polonya olup, onu Fransa takip etmektedir. Ardından köprü üstü simülatörü açısından Türkiye Endonezya'dan daha fazla sayıa sahipken, makine simülatörü olarak Endonezya Türkiye'den daha fazla simülatöre sahiptir.

Şekil 4'de simülatörlerin bulundukları lokasyona (ülkelerin illerine göre) göre dağılımları gösterilmektedir. Buna göre, toplam 46 adet simülatör sayısı ile en fazla simülatöre sahip olan şehir Polonya'nın Szczecin şehridir. Dünya sıralamasında $\% \quad 6.8^{\prime}$ lik dilim içerisindedir. İkinci sırada toplam 41 adet simülatör sayısı (\% 6.1) ile yine Polonya'ya bağlı Gdynia şehri gelmektedir. Polonya'dan sonra en fazla simülatöre sahip şehir 31 adet simülatörü $\left(\begin{array}{ll}\% & 4.6\end{array}\right)$ ile Türkiye'den
İstanbul'dur. Dördüncü sirada 21 adet simülatörü (\% 3.1) ile Gürcistan' a bağl1 Batum ve beşinci surada 20 adet simülatörü (\% 3.0) ile Romanya'ya bağlı Köstence gelmektedir. Ülke olarak bakıldığında, Gürcistan toplam sahip olduğu simülatör sayısı bakımından sekizinci siradayken (\% 3.1), Romanya onuncu siradadır (\% 3.0). Ancak üst siralarda yer alan ülkelerin daha fazla şehir sayısı olduğu için toplamdaki simülatör sayıları daha fazla gözükmektedir.

Şekil 5 'te simülatör tiplerinin lokasyonlara göre dağılımı gösterilmektedir. Dünya'da en fazla köprü üstü ve makine simülatörü bulunan şehir sirasiyla 11 adet ve 10 adet ile Szczecin'dir. Ardından, Batum, Gdynia ve İstanbul illeri 6 adet köprü üstü simülatörü ile aynı sırayı paylaşmaktadır. Diğer taraftan Polonya'nın Kedzierzyn-Kozle şehrinde, Letonya'nın Liepaja şehrinde ve Tayland'in Nakhon Si Thammarat şehrinde hiç köprü üstü simülatörü bulunmamaktadır. Makine köprü üstü simülatöründe Gdynia'dan sonra Türkiye'nin İstanbul şehri ve Polonya'nın Kolobrzeg şehri 5 adet simülatör sayıs1 ile aynı sıray paylaşmaktadır. 103 lokasyonun 23 adet şehrinde hiç makine simülatörü bulunmamaktadır.

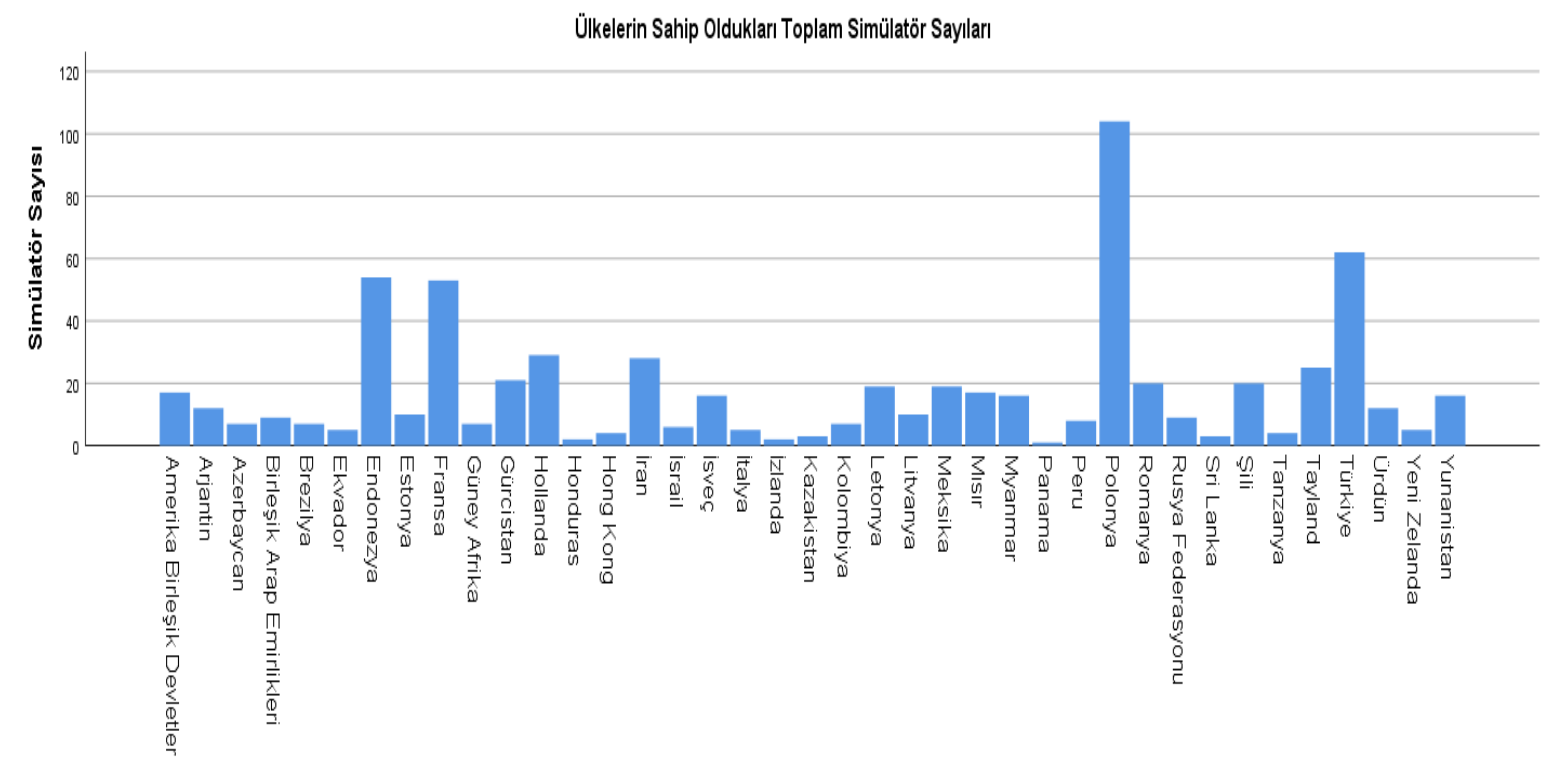

Ülke

Şekil 2. Ülkelerin sahip oldukları toplam simülatör sayılarına göre dağılımı. 


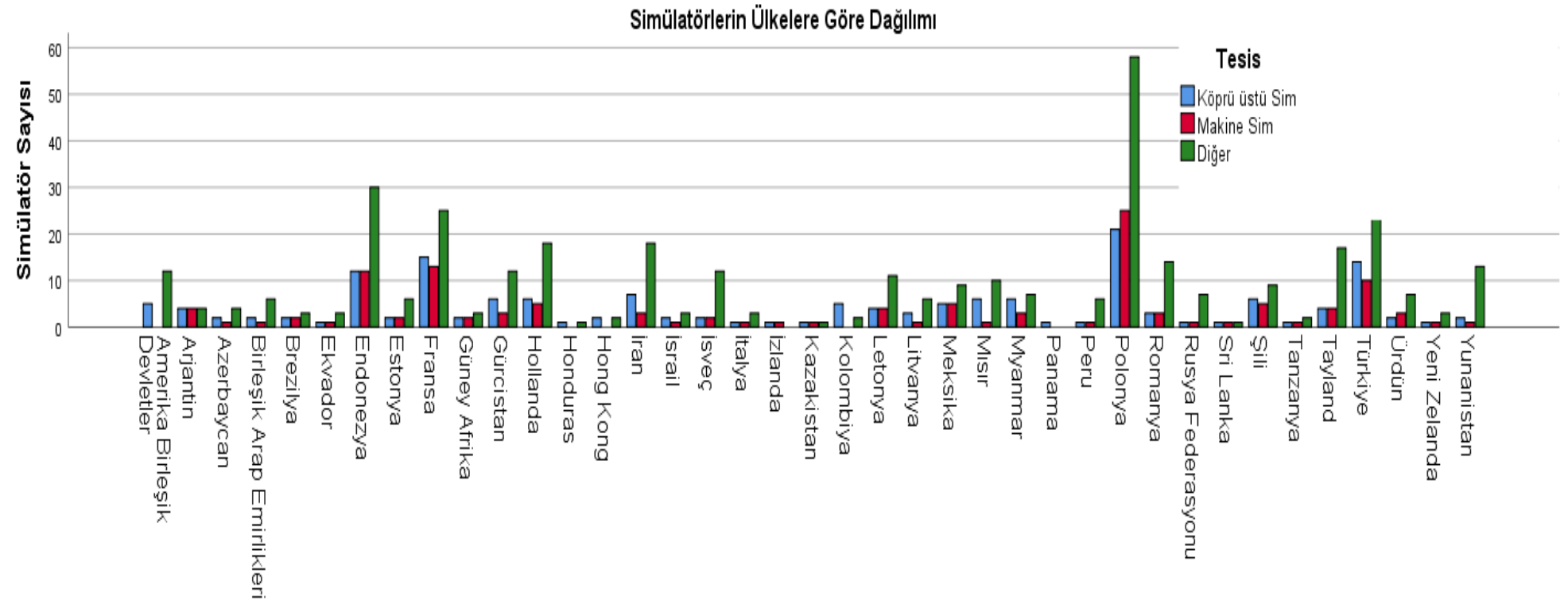

Ülke

Şekil 3. Simülatör tiplerinin ülkelere göre dağılımı. 
Lokasyonların Sahip Oldukları Toplam Simülatör Sayıları

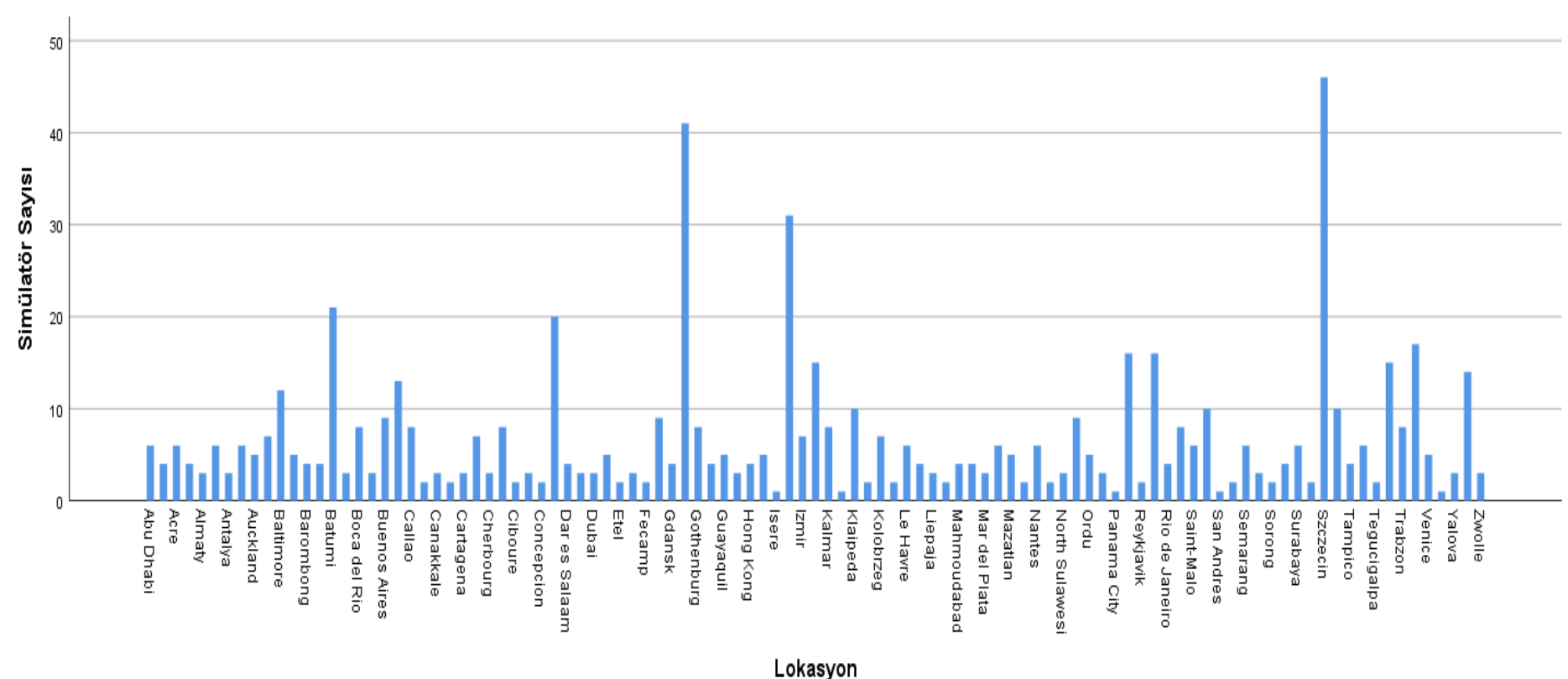

Şekil 4. Lokasyonların sahip oldukları toplam simülatör sayılarına göre dağılımı. 


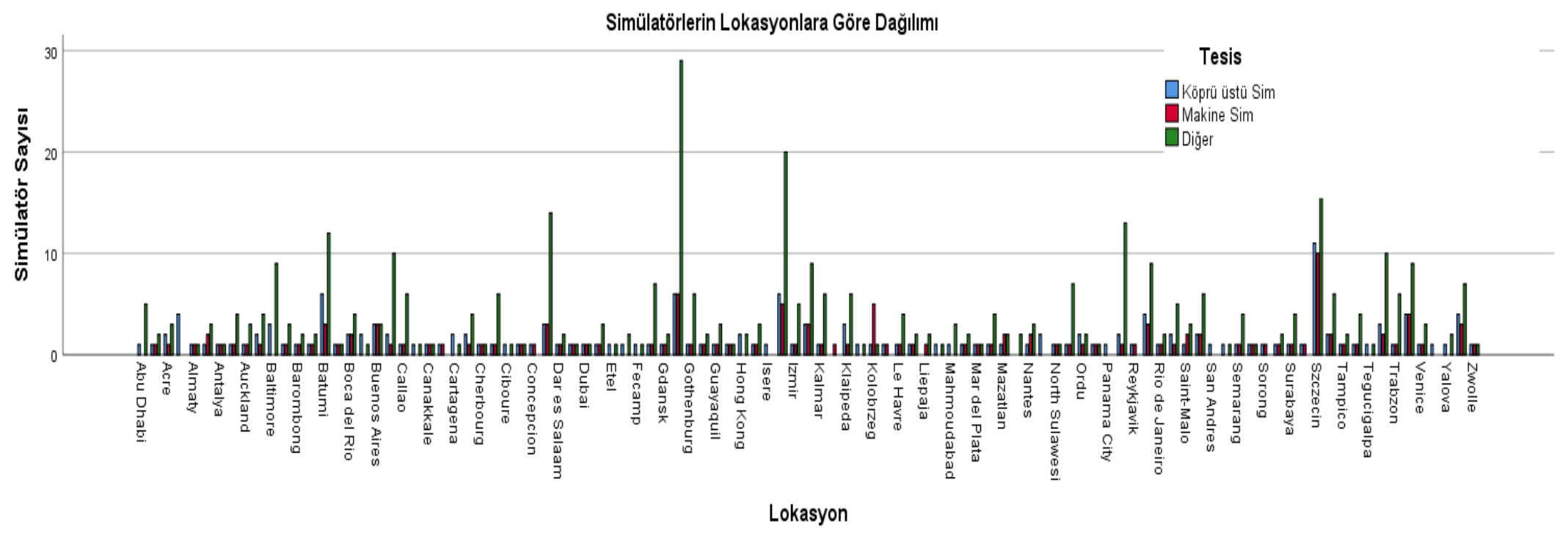

Şekil 5. Simülatörler tiplerinin lokasyonlara göre dă̆ılımı. 
Simülatör tiplerinin dağılımında ülkelerin ve lokasyonların anlamlı birer grup değişkeni olup olmadıklarını anlamak ve anlamlı şekilde kümelenmeler oluşturup oluşturmadığını tespit etmek amaciyla K-ortalamalar tekniği kullanılmıştır. $\mathrm{Bu}$ bağlamda her bir veri örneğinin küme dağılımları Tablo 1'de gösterilmiştir. Analiz sonucuna göre elde edilen anlamlılık değeri uygun şekilde çıtığından $(p<0.05)$ Tablo 1'e göre her kümenin ülke, lokasyon ve simülatör tip özellikleri çıkartılabilir.

Tablo 2'de ülke ve lokasyon grup değişkenlerinin tesis değişkeni üzerinde anlamlı bir farklılık oluşturup oluşturmadığının sonucu yer almaktadır. $\mathrm{Bu}$ amaçla Kruskal Wallis $-\mathrm{H}$ testi yapılmıştır. Kruskal Wallis $-\mathrm{H}$ testi, normal dağılım göstermeyen veriler de gruplar arasında anlamlı bir farklılık olup olmadığını test etmek amaciyla kullanılır (Ostertagová et al., 2014). Tablo 2'ye göre, ülke ve lokasyon değişkenleri tesis değişkeni üzerinde anlamlı bir farkl111k göstermektedir $(\mathrm{p}<0.05)$.

Tablo 3'de değişkenlerin tesis üzerindeki ortalama değerleri gösterilmiştir. Buna göre, hangi değişkenin hangi simülatör tipi üzerinde daha fazla farklılık gösterdiği çıkarılabilir.
Tablo 1. Kruskal Wallis test

\begin{tabular}{lcc}
\hline \multicolumn{3}{c}{ Test İstatistik $\mathbf{k}^{\mathbf{a}, \mathbf{b}}$} \\
\hline & $\ddot{U ̈ l k e}$ & Lokasyon $^{3}$ \\
\hline Kruskal-Wallis H & 6,928 & 6,886 \\
df & 2 & 2 \\
Asymp.Sig. &, 031 &, 032 \\
\hline \multicolumn{2}{l}{ a.Kruskal Wallis Test } \\
b.Grup Değişkeni: Tesis \\
\hline
\end{tabular}

Tablo 2. Değişkenlerin tesis üzerindeki ortalamalart.

\begin{tabular}{|c|c|c|c|}
\hline \multicolumn{4}{|c|}{ Siralama } \\
\hline & Tesis & $\mathbf{N}$ & Ortalama \\
\hline \multirow{4}{*}{ Ülke } & $\begin{array}{c}\text { Köprü } \\
\text { üstü }\end{array}$ & 163 & 309,42 \\
\hline & Makine & 125 & 322,94 \\
\hline & Diğer & 386 & 354,08 \\
\hline & Toplam & 674 & \\
\hline \multirow{4}{*}{ Lokasyon } & $\begin{array}{c}\text { Köprü } \\
\text { üstü }\end{array}$ & 163 & 305,79 \\
\hline & Makine & 125 & 331,18 \\
\hline & Diğer & 386 & 352,94 \\
\hline & Toplam & 674 & \\
\hline
\end{tabular}


Tablo 3. K-ortalamalar tekniği ile kümeleme analizi sonuçları.

\begin{tabular}{|c|c|c|c|c|c|c|c|c|c|c|c|c|c|c|c|c|c|}
\hline $\begin{array}{c}\text { Veri } \\
\text { No }\end{array}$ & Küme & Uzaklık & $\begin{array}{l}\text { Veri } \\
\text { No }\end{array}$ & Küme & Uzaklık & $\begin{array}{c}\text { Veri } \\
\text { No }\end{array}$ & Küme & Uzaklık & $\begin{array}{c}\text { Veri } \\
\text { No }\end{array}$ & Küme & Uzaklık & $\begin{array}{c}\text { Veri } \\
\text { No }\end{array}$ & Küme & Uzaklık & $\begin{array}{c}\text { Veri } \\
\text { No }\end{array}$ & Küme & Uzaklık \\
\hline 1 & 1 & 18,033 & 121 & 2 & 10,156 & 241 & 2 & 11,021 & 361 & 1 & 13,453 & 481 & 3 & 12,173 & 601 & 2 & 3,848 \\
\hline 2 & 1 & 17,103 & 122 & 2 & 10,156 & 242 & 2 & 10,065 & 362 & 1 & 13,453 & 482 & 3 & 12,173 & 602 & 2 & 3,848 \\
\hline 3 & 1 & 17,103 & 123 & 2 & 10,156 & 243 & 2 & 10,065 & 363 & 1 & 13,453 & 483 & 3 & 13,065 & 603 & 2 & 4,545 \\
\hline 4 & 1 & 17,103 & 124 & 2 & 10,156 & 244 & 2 & 10,065 & 364 & 1 & 13,453 & 484 & 3 & 13,065 & 604 & 2 & 4,545 \\
\hline 5 & 1 & 15,816 & 125 & 2 & 9,219 & 245 & 2 & 10,065 & 365 & 1 & 13,453 & 485 & 3 & 13,065 & 605 & 2 & 4,545 \\
\hline 6 & 1 & 15,816 & 126 & 2 & 8,297 & 246 & 2 & 10,065 & 366 & 1 & 13,453 & 486 & 3 & 13,065 & 606 & 2 & 4,545 \\
\hline 7 & 1 & 14,553 & 127 & 2 & 7,395 & 247 & 2 & 11,021 & 367 & 1 & 14,650 & 487 & 3 & 13,065 & 607 & 2 & 4,545 \\
\hline 8 & 1 & 13,606 & 128 & 2 & 6,521 & 248 & 2 & 11,021 & 368 & 1 & 14,650 & 488 & 3 & 13,065 & 608 & 2 & 4,545 \\
\hline 9 & 1 & 12,359 & 129 & 2 & 5,219 & 249 & 2 & 11,021 & 369 & 1 & 14,650 & 489 & 3 & 13,065 & 609 & 2 & 22,621 \\
\hline 10 & 1 & 12,359 & 130 & 2 & 5,219 & 250 & 2 & 10,065 & 370 & 1 & 14,650 & 490 & 3 & 13,972 & 610 & 2 & 22,621 \\
\hline 11 & 1 & 12,359 & 131 & 2 & 5,219 & 251 & 2 & 10,065 & 371 & 1 & 14,650 & 491 & 3 & 13,972 & 611 & 2 & 5,339 \\
\hline 12 & 1 & 12,359 & 132 & 2 & 3,994 & 252 & 2 & 10,065 & 372 & 1 & 14,650 & 492 & 3 & 14,891 & 612 & 2 & 5,339 \\
\hline 13 & 1 & 11,405 & 133 & 2 & 2,943 & 253 & 2 & 10,065 & 373 & 1 & 14,650 & 493 & 3 & 14,891 & 613 & 2 & 5,339 \\
\hline 14 & 1 & 10,460 & 134 & 2 & 2,123 & 254 & 2 & 10,065 & 374 & 1 & 14,650 & 494 & 3 & 14,891 & 614 & 2 & 5,339 \\
\hline 15 & 1 & 9,222 & 135 & 2 & 1,794 & 255 & 2 & 9,119 & 375 & 1 & 14,650 & 495 & 3 & 15,820 & 615 & 2 & 5,339 \\
\hline 16 & 1 & 9,222 & 136 & 2 & 2,435 & 256 & 2 & 8,185 & 376 & 1 & 14,650 & 496 & 2 & 14,882 & 616 & 2 & 5,339 \\
\hline 17 & 1 & 8,269 & 137 & 2 & 2,788 & 257 & 2 & 7,269 & 377 & 1 & 14,650 & 497 & 2 & 14,882 & 617 & 2 & 6,724 \\
\hline 18 & 1 & 8,269 & 138 & 2 & 4,060 & 258 & 2 & 7,269 & 378 & 1 & 14,650 & 498 & 2 & 14,882 & 618 & 2 & 7,554 \\
\hline 19 & 1 & 7,329 & 139 & 2 & 4,726 & 259 & 2 & 7,269 & 379 & 1 & 14,650 & 499 & 2 & 12,285 & 619 & 2 & 7,554 \\
\hline 20 & 1 & 6,111 & 140 & 2 & 5,493 & 260 & 2 & 7,269 & 380 & 1 & 15,882 & 500 & 2 & 12,285 & 620 & 2 & 7,554 \\
\hline 21 & 1 & 4,998 & 141 & 2 & 5,493 & 261 & 2 & 7,269 & 381 & 1 & 17,143 & 501 & 2 & 12,285 & 621 & 2 & 7,554 \\
\hline 22 & 1 & 4,998 & 142 & 2 & 6,848 & 262 & 2 & 6,379 & 382 & 1 & 17,143 & 502 & 2 & 12,285 & 622 & 2 & 7,554 \\
\hline 23 & 1 & 4,998 & 143 & 2 & 7,664 & 263 & 2 & 21,645 & 383 & 3 & 15,865 & 503 & 2 & 12,285 & 623 & 2 & 7,554 \\
\hline 24 & 1 & 4,998 & 144 & 2 & 7,664 & 264 & 2 & 5,040 & 384 & 3 & 14,907 & 504 & 2 & 12,285 & 624 & 2 & 7,554 \\
\hline 25 & 1 & 4,039 & 145 & 2 & 8,519 & 265 & 2 & 5,040 & 385 & 3 & 14,907 & 505 & 2 & 11,028 & 625 & 2 & 7,554 \\
\hline 26 & 1 & 4,039 & 146 & 2 & 7,664 & 266 & 2 & 5,040 & 386 & 3 & 13,955 & 506 & 2 & 11,028 & 626 & 2 & 8,420 \\
\hline 27 & 1 & 3,154 & 147 & 2 & 9,404 & 267 & 2 & 3,756 & 387 & 3 & 13,955 & 507 & 2 & 11,028 & 627 & 2 & 7,554 \\
\hline 28 & 1 & 3,154 & 148 & 2 & 10,309 & 268 & 2 & 2,612 & 388 & 3 & 12,073 & 508 & 2 & 11,028 & 628 & 2 & 7,554 \\
\hline 29 & 1 & 2,754 & 149 & 2 & 11,230 & 269 & 2 & 1,633 & 389 & 3 & 12,073 & 509 & 2 & 11,028 & 629 & 2 & 9,314 \\
\hline 30 & 1 & 2,217 & 150 & 2 & 11,230 & 270 & 2 & 1,174 & 390 & 3 & 12,073 & 510 & 2 & 11,028 & 630 & 2 & 10,227 \\
\hline 31 & 1 & 2,061 & 151 & 2 & 12,164 & 271 & 2 & 2,023 & 391 & 3 & 12,073 & 511 & 2 & 11,028 & 631 & 2 & 10,227 \\
\hline 32 & 1 & 2,362 & 152 & 2 & 7,664 & 272 & 2 & 2,436 & 392 & 3 & 11,148 & 512 & 2 & 11,028 & 632 & 2 & 10,227 \\
\hline 33 & 1 & 2,985 & 153 & 2 & 7,664 & 273 & 2 & 3,827 & 393 & 3 & 11,148 & 513 & 2 & 11,028 & 633 & 2 & 10,227 \\
\hline 34 & 1 & 3,774 & 154 & 2 & 7,664 & 274 & 2 & 4,527 & 394 & 3 & 11,148 & 514 & 2 & 11,028 & 634 & 2 & 10,227 \\
\hline 35 & 1 & 4,645 & 155 & 2 & 13,108 & 275 & 2 & 5,323 & 395 & 3 & 11,148 & 515 & 2 & 11,028 & 635 & 2 & 10,227 \\
\hline 36 & 1 & 5,559 & 156 & 2 & 14,371 & 276 & 2 & 5,323 & 396 & 3 & 11,148 & 516 & 2 & 11,028 & 636 & 2 & 11,155 \\
\hline 37 & 1 & 6,499 & 157 & 2 & 15,309 & 277 & 2 & 6,712 & 397 & 3 & 11,148 & 517 & 2 & 11,028 & 637 & 2 & 11,155 \\
\hline 38 & 1 & 7,454 & 158 & 2 & 16,585 & 278 & 2 & 7,543 & 398 & 3 & 10,237 & 518 & 2 & 11,028 & 638 & 2 & 12,095 \\
\hline 39 & 1 & 8,420 & 159 & 2 & 17,883 & 279 & 2 & 7,543 & 399 & 3 & 10,237 & 519 & 2 & 11,028 & 639 & 2 & 12,095 \\
\hline
\end{tabular}


Tablo 4 (Devamı). K-ortalamalar tekniği ile kümeleme analizi sonuçları.

\begin{tabular}{|c|c|c|c|c|c|c|c|c|c|c|c|c|c|c|c|c|c|}
\hline 40 & 1 & 9,393 & 160 & 2 & 18,805 & 280 & 2 & 8,411 & 400 & 3 & 9,344 & 520 & 2 & 10,073 & 640 & 2 & 12,095 \\
\hline 41 & 1 & 10,371 & 161 & 2 & 18,805 & 281 & 2 & 7,543 & 401 & 3 & 9,344 & 521 & 2 & 10,073 & 641 & 2 & 12,095 \\
\hline 42 & 1 & 11,353 & 162 & 2 & 18,805 & 282 & 2 & 10,219 & 402 & 3 & 9,344 & 522 & 2 & 10,073 & 642 & 2 & 12,095 \\
\hline 43 & 1 & 12,338 & 163 & 2 & 19,735 & 283 & 2 & 11,148 & 403 & 3 & 9,344 & 523 & 2 & 10,073 & 643 & 2 & 7,554 \\
\hline 44 & 1 & 13,486 & 164 & 1 & 17,061 & 284 & 2 & 12,088 & 404 & 3 & 8,476 & 524 & 2 & 10,073 & 644 & 2 & 7,554 \\
\hline 45 & 1 & 13,486 & 165 & 1 & 17,993 & 285 & 2 & 7,543 & 405 & 3 & 8,476 & 525 & 2 & 10,073 & 645 & 2 & 7,554 \\
\hline 46 & 1 & 13,486 & 166 & 1 & 17,061 & 286 & 2 & 7,543 & 406 & 3 & 7,639 & 526 & 2 & 10,073 & 646 & 2 & 7,554 \\
\hline 47 & 1 & 13,486 & 167 & 1 & 17,061 & 287 & 2 & 15,249 & 407 & 3 & 7,639 & 527 & 2 & 10,073 & 647 & 2 & 7,554 \\
\hline 48 & 1 & 13,486 & 168 & 1 & 15,770 & 288 & 2 & 16,530 & 408 & 3 & 7,639 & 528 & 2 & 10,073 & 648 & 2 & 7,554 \\
\hline 49 & 1 & 13,486 & 169 & 1 & 14,503 & 289 & 1 & 18,008 & 409 & 3 & 7,639 & 529 & 2 & 11,028 & 649 & 2 & 7,554 \\
\hline 50 & 1 & 14,680 & 170 & 1 & 13,553 & 290 & 1 & 17,077 & 410 & 3 & 11,148 & 530 & 2 & 11,028 & 650 & 2 & 7,554 \\
\hline 51 & 1 & 14,680 & 171 & 1 & 12,301 & 291 & 1 & 17,077 & 411 & 3 & 11,148 & 531 & 2 & 11,028 & 651 & 2 & 7,554 \\
\hline 52 & 1 & 15,910 & 172 & 1 & 12,301 & 292 & 1 & 17,077 & 412 & 3 & 11,148 & 532 & 2 & 11,028 & 652 & 2 & 7,554 \\
\hline 53 & 1 & 17,169 & 173 & 1 & 12,301 & 293 & 1 & 15,788 & 413 & 3 & 6,259 & 533 & 2 & 11,028 & 653 & 2 & 13,043 \\
\hline 54 & 1 & 17,169 & 174 & 1 & 12,301 & 294 & 1 & 15,788 & 414 & 3 & 6,259 & 534 & 2 & 11,028 & 654 & 2 & 13,043 \\
\hline 55 & 3 & 17,148 & 175 & 1 & 11,342 & 295 & 1 & 15,788 & 415 & 3 & 6,259 & 535 & 2 & 10,073 & 655 & 2 & 14,312 \\
\hline 56 & 3 & 15,902 & 176 & 1 & 5,992 & 296 & 1 & 15,788 & 416 & 3 & 6,259 & 536 & 2 & 11,028 & 656 & 2 & 14,312 \\
\hline 57 & 3 & 14,947 & 177 & 1 & 3,856 & 297 & 1 & 14,522 & 417 & 3 & 5,449 & 537 & 2 & 11,028 & 657 & 2 & 14,312 \\
\hline 58 & 3 & 13,997 & 178 & 1 & 2,917 & 298 & 1 & 14,522 & 418 & 3 & 5,449 & 538 & 2 & 11,028 & 658 & 2 & 15,254 \\
\hline 59 & 3 & 13,055 & 179 & 1 & 2,917 & 299 & 1 & 13,573 & 419 & 3 & 5,449 & 539 & 2 & 11,028 & 659 & 2 & 14,312 \\
\hline 60 & 3 & 12,123 & 180 & 1 & 2,478 & 300 & 1 & 12,323 & 420 & 3 & 5,449 & 540 & 2 & 11,028 & 660 & 2 & 14,312 \\
\hline 61 & 3 & 11,201 & 181 & 1 & 1,864 & 301 & 1 & 12,323 & 421 & 3 & 4,713 & 541 & 2 & 11,028 & 661 & 2 & 16,535 \\
\hline 62 & 3 & 11,201 & 182 & 1 & 9,316 & 302 & 1 & 12,323 & 422 & 3 & 4,713 & 542 & 2 & 11,028 & 662 & 2 & 16,535 \\
\hline 63 & 3 & 10,295 & 183 & 1 & 1,675 & 303 & 1 & 12,323 & 423 & 3 & 4,713 & 543 & 2 & 11,028 & 663 & 2 & 17,836 \\
\hline 64 & 3 & 9,408 & 184 & 1 & 2,034 & 304 & 1 & 12,323 & 424 & 3 & 4,713 & 544 & 2 & 10,073 & 664 & 2 & 17,836 \\
\hline 65 & 3 & 8,546 & 185 & 1 & 2,733 & 305 & 1 & 12,323 & 425 & 3 & 4,713 & 545 & 2 & 10,073 & 665 & 2 & 18,761 \\
\hline 66 & 3 & 7,717 & 186 & 1 & 3,578 & 306 & 1 & 12,323 & 426 & 3 & 4,713 & 546 & 2 & 10,073 & 666 & 2 & 18,761 \\
\hline 67 & 3 & 11,201 & 187 & 1 & 7,357 & 307 & 1 & 12,323 & 427 & 3 & 4,713 & 547 & 2 & 10,073 & 667 & 2 & 18,761 \\
\hline 68 & 3 & 6,353 & 188 & 1 & 1,864 & 308 & 1 & 12,323 & 428 & 3 & 4,713 & 548 & 2 & 10,073 & 668 & 2 & 18,761 \\
\hline 69 & 3 & 6,353 & 189 & 1 & 8,334 & 309 & 1 & 9,174 & 429 & 3 & 4,713 & 549 & 2 & 10,073 & 669 & 2 & 18,761 \\
\hline 70 & 3 & 5,557 & 190 & 1 & 9,316 & 310 & 1 & 8,216 & 430 & 3 & 4,713 & 550 & 2 & 10,073 & 670 & 2 & 18,761 \\
\hline 71 & 3 & 5,557 & 191 & 1 & 10,301 & 311 & 1 & 6,038 & 431 & 3 & 3,321 & 551 & 2 & 10,073 & 671 & 2 & 18,761 \\
\hline 72 & 3 & 4,838 & 192 & 1 & 11,289 & 312 & 1 & 6,038 & 432 & 3 & 3,321 & 552 & 2 & 10,073 & 672 & 2 & 18,761 \\
\hline 73 & 3 & 4,838 & 193 & 1 & 13,432 & 313 & 1 & 6,038 & 433 & 3 & 3,321 & 553 & 2 & 10,073 & 673 & 2 & 18,761 \\
\hline 74 & 3 & 4,838 & 194 & 1 & 13,432 & 314 & 1 & 3,928 & 434 & 3 & 1,963 & 554 & 2 & 10,073 & 674 & 2 & 19,693 \\
\hline 75 & 3 & 3,496 & 195 & 1 & 13,432 & 315 & 1 & 3,928 & 435 & 3 & 1,963 & 555 & 2 & 10,073 & & & \\
\hline 76 & 3 & 3,496 & 196 & 1 & 14,631 & 316 & 1 & 3,928 & 436 & 3 & 1,963 & 556 & 2 & 10,073 & & & \\
\hline 77 & 3 & 2,246 & 197 & 3 & 17,102 & 317 & 1 & 3,928 & 437 & 2 & 23,416 & 557 & 2 & 10,073 & & & \\
\hline 78 & 3 & 1,365 & 198 & 3 & 15,852 & 318 & 1 & 3,928 & 438 & 2 & 23,416 & 558 & 2 & 10,073 & & & \\
\hline 79 & 3 & 1,543 & 199 & 3 & 14,893 & 319 & 1 & 3,928 & 439 & 2 & 23,416 & 559 & 2 & 9,128 & & & \\
\hline 80 & 3 & 2,281 & 200 & 3 & 13,940 & 320 & 1 & 3,928 & 440 & 3 & 1,091 & 560 & 2 & 9,128 & & & \\
\hline
\end{tabular}


Tablo 5 (Devamı). K-ortalamalar tekniği ile kümeleme analizi sonuçları.

\begin{tabular}{|c|c|c|c|c|c|c|c|c|c|c|c|c|c|c|}
\hline 81 & 3 & 3,467 & 201 & 3 & 12,994 & 321 & 1 & 3,928 & 441 & 3 & 1,091 & 561 & 2 & 8,195 \\
\hline 82 & 3 & 3,467 & 202 & 3 & 12,057 & 322 & 1 & 3,928 & 442 & 3 & 1,091 & 562 & 2 & 7,280 \\
\hline 83 & 3 & 3,467 & 203 & 3 & 11,130 & 323 & 1 & 3,928 & 443 & 3 & 1,091 & 563 & 2 & 5,056 \\
\hline 84 & 3 & 3,467 & 204 & 3 & 11,130 & 324 & 1 & 3,011 & 444 & 3 & 2,003 & 564 & 2 & 5,056 \\
\hline 85 & 3 & 4,779 & 205 & 3 & 10,217 & 325 & 1 & 3,011 & 445 & 2 & 23,236 & 565 & 2 & 5,056 \\
\hline 86 & 3 & 4,779 & 206 & 3 & 9,323 & 326 & 1 & 3,011 & 446 & 2 & 23,236 & 566 & 2 & 5,056 \\
\hline 87 & 3 & 4,779 & 207 & 3 & 8,452 & 327 & 1 & 3,011 & 447 & 3 & 3,291 & 567 & 2 & 5,056 \\
\hline 88 & 3 & 6,137 & 208 & 3 & 7,613 & 328 & 1 & 3,011 & 448 & 3 & 3,291 & 568 & 2 & 5,056 \\
\hline 89 & 3 & 6,941 & 209 & 3 & 11,130 & 329 & 1 & 3,011 & 449 & 3 & 3,291 & 569 & 2 & 5,056 \\
\hline 90 & 3 & 7,791 & 210 & 3 & 6,227 & 330 & 1 & 2,588 & 450 & 3 & 3,291 & 570 & 2 & 5,056 \\
\hline 91 & 3 & 8,673 & 211 & 3 & 4,670 & 331 & 1 & 2,588 & 451 & 3 & 3,291 & 571 & 2 & 5,056 \\
\hline 92 & 3 & 8,673 & 212 & 3 & 4,670 & 332 & 1 & 2,588 & 452 & 3 & 3,291 & 572 & 2 & 5,056 \\
\hline 93 & 3 & 10,002 & 213 & 3 & 3,260 & 333 & 1 & 2,588 & 453 & 3 & 3,291 & 573 & 2 & 5,056 \\
\hline 94 & 3 & 10,002 & 214 & 3 & 1,857 & 334 & 1 & 2,008 & 454 & 3 & 3,291 & 574 & 2 & 5,056 \\
\hline 95 & 3 & 10,888 & 215 & 2 & 23,413 & 335 & 1 & 2,008 & 455 & 3 & 3,291 & 575 & 2 & 5,056 \\
\hline 96 & 3 & 10,888 & 216 & 2 & 23,413 & 336 & 1 & 2,008 & 456 & 3 & 4,653 & 576 & 2 & 5,056 \\
\hline 97 & 3 & 10,002 & 217 & 3 & ,887 & 337 & 1 & 9,346 & 457 & 3 & 4,653 & 577 & 2 & 3,778 \\
\hline 98 & 3 & 10,002 & 218 & 3 & 1,899 & 338 & 1 & 9,346 & 458 & 3 & 4,653 & 578 & 2 & 3,778 \\
\hline 99 & 3 & 12,222 & 219 & 2 & 23,232 & 339 & 1 & 1,834 & 459 & 3 & 4,653 & 579 & 2 & 3,778 \\
\hline 100 & 3 & 12,222 & 220 & 3 & 3,229 & 340 & 1 & 1,834 & 460 & 3 & 4,653 & 580 & 2 & 3,778 \\
\hline 101 & 3 & 13,111 & 221 & 3 & 3,229 & 341 & 1 & 1,834 & 461 & 3 & 4,653 & 581 & 2 & 3,778 \\
\hline 102 & 3 & 14,015 & 222 & 3 & 3,229 & 342 & 1 & 1,834 & 462 & 3 & 6,039 & 582 & 2 & 3,778 \\
\hline 103 & 3 & 14,931 & 223 & 3 & 4,610 & 343 & 1 & 2,167 & 463 & 3 & 6,855 & 583 & 2 & 3,778 \\
\hline 104 & 3 & 15,857 & 224 & 3 & 6,825 & 344 & 1 & 2,167 & 464 & 3 & 6,855 & 584 & 2 & 2,643 \\
\hline 105 & 2 & 14,939 & 225 & 3 & 7,688 & 345 & 1 & 2,833 & 465 & 3 & 7,714 & 585 & 2 & 2,643 \\
\hline 106 & 2 & 13,634 & 226 & 3 & 6,825 & 346 & 1 & 2,833 & 466 & 3 & 7,714 & 586 & 2 & 2,643 \\
\hline 107 & 2 & 12,353 & 227 & 3 & 8,580 & 347 & 1 & 3,655 & 467 & 3 & 8,604 & 587 & 2 & 1,241 \\
\hline 108 & 2 & 11,104 & 228 & 3 & 8,580 & 348 & 1 & 4,549 & 468 & 3 & 8,604 & 588 & 2 & 2,062 \\
\hline 109 & 2 & 11,104 & 229 & 3 & 9,922 & 349 & 1 & 5,479 & 469 & 3 & 8,604 & 589 & 2 & 2,062 \\
\hline 110 & 2 & 11,104 & 230 & 3 & 9,922 & 350 & 1 & 6,431 & 470 & 3 & 8,604 & 590 & 2 & 2,062 \\
\hline 111 & 2 & 11,104 & 231 & 3 & 9,922 & 351 & 1 & 8,368 & 471 & 3 & 9,942 & 591 & 2 & 2,062 \\
\hline 112 & 2 & 10,156 & 232 & 3 & 12,157 & 352 & 1 & 9,346 & 472 & 3 & 9,942 & 592 & 2 & 2,062 \\
\hline 113 & 2 & 10,156 & 233 & 3 & 13,050 & 353 & 1 & 10,329 & 473 & 3 & 9,942 & 593 & 2 & 2,062 \\
\hline 114 & 2 & 10,156 & 234 & 3 & 13,958 & 354 & 1 & 11,314 & 474 & 3 & 9,942 & 594 & 2 & 2,469 \\
\hline 115 & 2 & 10,156 & 235 & 3 & 14,877 & 355 & 1 & 13,453 & 475 & 3 & 9,942 & 595 & 2 & 2,469 \\
\hline 116 & 2 & 10,156 & 236 & 3 & 15,807 & 356 & 1 & 13,453 & 476 & 3 & 9,942 & 596 & 2 & 2,469 \\
\hline 117 & 2 & 11,104 & 237 & 2 & 14,877 & 357 & 1 & 13,453 & 477 & 3 & 9,942 & 597 & 2 & 2,469 \\
\hline 118 & 2 & 10,156 & 238 & 2 & 12,278 & 358 & 1 & 13,453 & 478 & 3 & 12,173 & 598 & 2 & 2,469 \\
\hline 119 & 2 & 11,104 & 239 & 2 & 11,021 & 359 & 1 & 13,453 & 479 & 3 & 12,173 & 599 & 2 & 2,469 \\
\hline 120 & 2 & 10,156 & 240 & 2 & 11,021 & 360 & 1 & 13,453 & 480 & 3 & 12,173 & 600 & 2 & 3,848 \\
\hline
\end{tabular}




\section{Tartışma}

Kümelerin bünyesinde bulundurduğu ülke, lokasyon ve simülatör değişkenleri incelendiğinde Şekil 6,7 ve 8 'deki gibi dağılımlar elde edilmiştir. Buna göre, Küme 1 de en fazla ortalamaya sahip olan ülkeler sırasıyla, Fransa, Gürcistan ve Şili'dir, en fazla ortalamaya sahip lokasyonlar ise sirasiyla Batum, Valparaiso ve Pire'dir. Küme 2 de ağırlıklı olan ülkeler sırasıyla Polonya, Türkiye ve Tayland'dır, ağırlıklı olan lokasyonlar ise sirasiyla Gdynia, Szczecin ve İstanbul'dur. Küme 3 de ise en fazla Endonezya, Hollanda ve İran ülkelerinin etkisi gözükürken, en fazla Rio de Janeiro, Kalmar, Trabzon şehirlerinin etkisi gözükmektedir. Her üç kümede de köprü üstü ve makine simülatörlerinin dışında kalan simülatör tipleri hakimdir. Diğer taraftan her üç kümede köprü üstü ve makine simülatörlerinin dağılımları kendi içlerinde birbirlerine oldukça yakın sayıda gözükmektedir. Buradan simülatörler tiplerinin kümeler arasında ayırıcı bir özellikte olmadığı anlaşılmaktadır. Ancak Tablo 2'deki Kruskal-Wallis testine göre ülke ve şehirlerin simülatör tipleri üzerinde anlamlı bir farklılık oluşturduğu sonucuna ulaşılmıştır. Tablo 3'e göre ülkelerin ve şehirlerin anlamlı farklılık gösterdiği simülatör tipleri sırasıyla diğer simülatörler, makine ve köprü üstü simülatörleridir.

Analiz sonuçlarına göre ülkeler arasında ayırıcı özellikte bulunan ülkelerin Polonya, Türkiye, Endonezya ve Fransa olduğu görülürken, en belirgin şehirlerin Szczecin, Gdynia, Köstence, Batum, ve İstanbul olduğu görülmektedir. Elde edilen sonuçlara göre bu ülkeler ve şehirler denizcilik kurumlarında kullandıkları simülatör tipleri ve sayılarına göre diğer ülkelerden önemli ölçüde ayrışmaktadır (Tablo 2'de $\mathrm{p}<0.05$ ).

Szczecin şehri Polonya'nın Baltık Denizi'ne bakan en büyük deniz limanıdır. Bu şehirde bulunan denizcilik üniversitesi Polonya'nın en önemli devlet üniversitelerinden biridir. Üniversite bünyesinde seyir fakültesi, denizcilik mühendisliği fakültesi, ekonomi ve ulaştırma fakültesi, mekatronik ve elektrik mühendisliği fakültesi ve bilgisayar bilimleri ve telekomünikasyon fakültesi olmak üzere beş farklı fakülte bulundurmaktadır (Url-2) .

Gdynia, Polonya'nın Pomeranya Bölgesi'nde bulunan ve Baltık Denizi'nin güney kıyısında yer alan Gdańsk Körfezi'nde önemli bir limanı bulunan bir şehirdir kentidir. Gdynia Denizcilik Üniversitesi Polonya'nın ve Avrupa'nın en büyük denizcilik devlet üniversitesidir. Üniversite, seyir, deniz mühendisliği, deniz elektrik mühendisliği ve işletme olarak dört fakülteden oluşmaktadır (Url-3).

Köstence Karadeniz kıyısındaki en büyük liman şehridir. Köstence Denizcilik Üniversitesi, seyir ve deniz taşımacılığı fakültesi ve deniz mühendisliği olarak iki ayrı fakülteden oluşur (Url-4).

Batum, Gürcistan'ın başkenti ve Karadeniz kıyısındaki önemli bir liman ve ticaret merkezi olan şehridir. Şehirde bulunan Batum Denizcilik Akademisi, seyir, deniz mühendisliği ve işletme fakültelerinden oluşur. Her bir fakülte denizciliğin ayrı dallarını içeren programlara sahiptir (Url-5).

İstanbul ise Türkiye'nin en önemli, kalabalı, tarihi, ekonomik ve sosyo-kültürel açıdan en değerli şehirlerinden biridir. İstanbul'da denizcilik eğitimi veren üniversiteler İstanbul Teknik Üniversitesi, Yıldı Teknik Üniversitesi, İstanbul Üniversitesi, Piri Reis Üniversitesidir (Url-6). Ancak bu üniversiteler analiz sonucu önde gelen diğer şehirlerde yer alan üniversiteler gibi başlı başına bir denizcilik üniversiteleri değildir. Her bir üniversitenin altında yer alan denizcilik ile ilgili birer fakültedir. Analiz sonucunda ayırıcı özelliği olan ülkeler şehirlerinde barındırdıkları bir ya da iki adet denizcilik üniversitesi ile simülatör tesisi bakımından kümelerde ağırlık gösterirken Türkiye, İstanbul şehrinde bulundurduğu denizcilik fakülteleri ile bu bakımdan öne çıkmaktadır.

Gelecek çalışmalarda, öncü şehirlerin denizcilik üniversitelerindeki öğrenci kapasitesi ve eğitim imkânları ile İstanbul şehrinin denizcilik fakültelerinin aynı değişkenleri kıyaslanarak simülatör tiplerine göre eğitim modellerinin SWOT analizleri yapılabilir. 


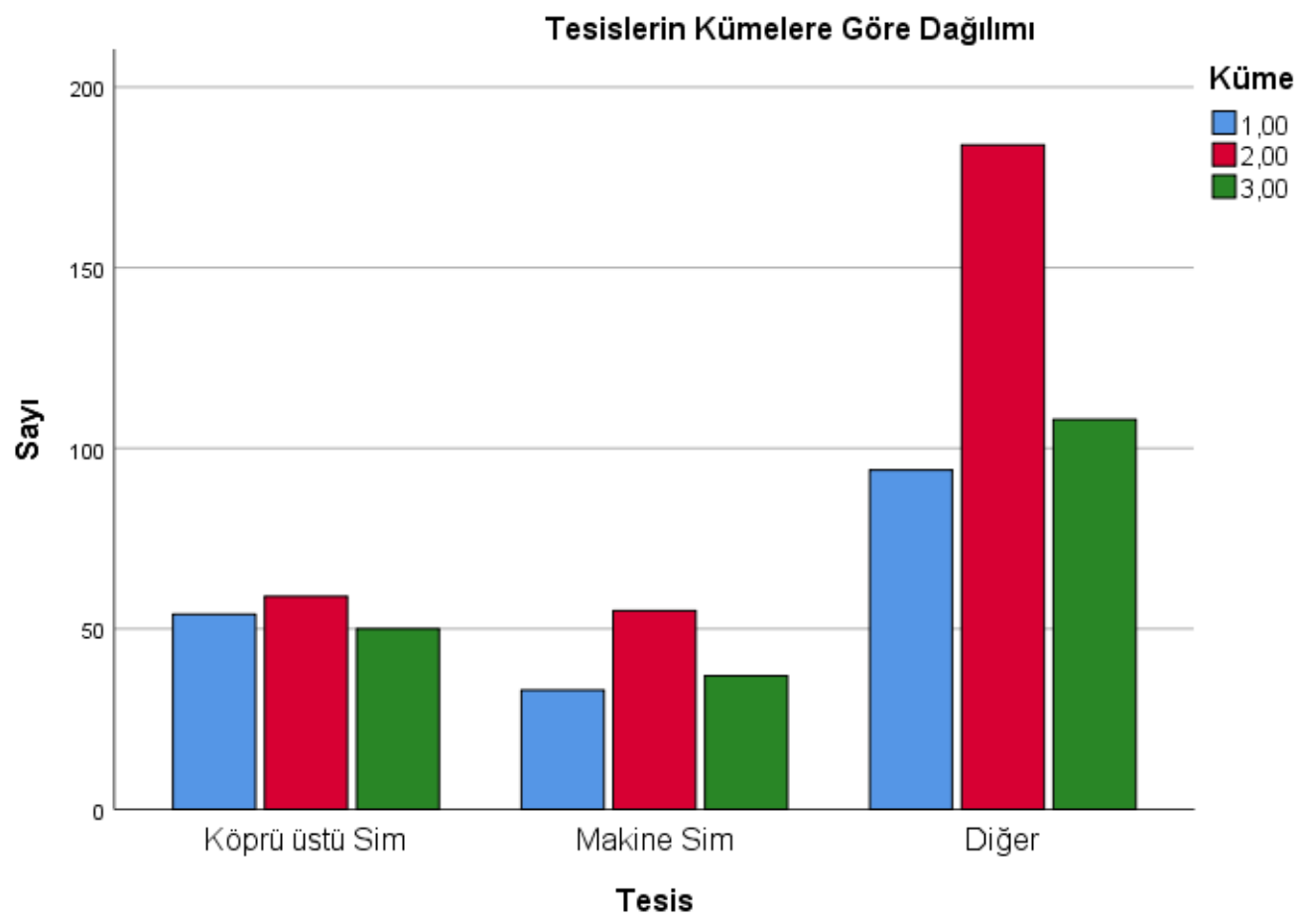

Şekil 6. Tesislerin kümelere göre dağılımı. 


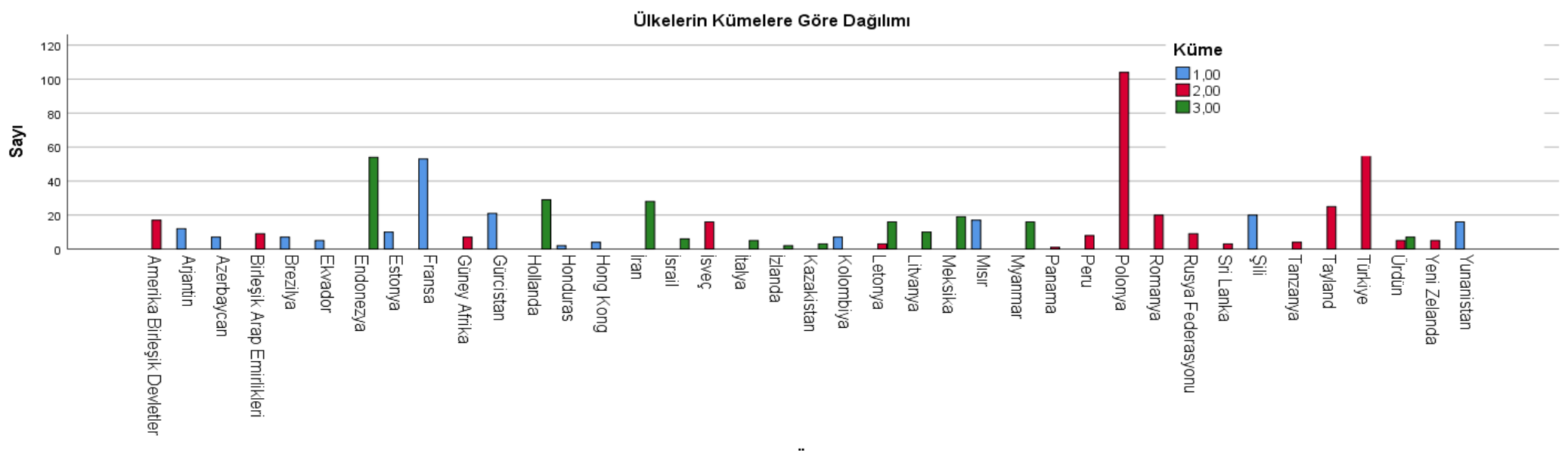

Ülke

Şekil 7. Ülkelerin kümeler arasındaki dă̆ılımı.

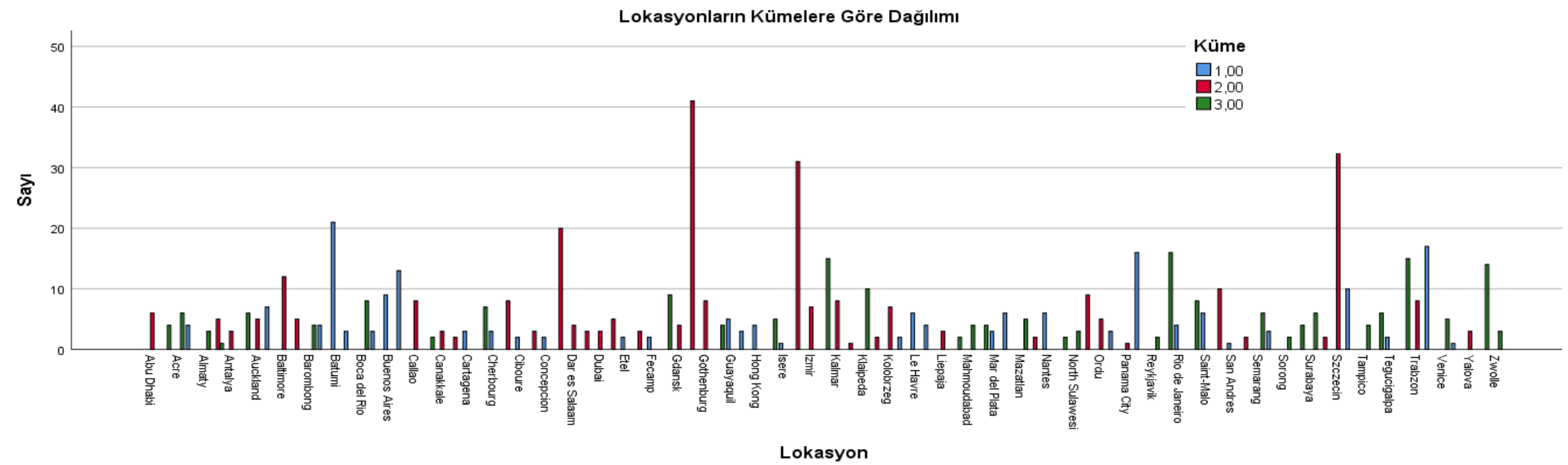

Şekil 8. Lokasyonların kümeler arasındaki dağılımı. 


\section{Destek ve Teşekkür Beyanı}

Teşekkür edilecek bir kurum ya da kuruluş bulunmamaktadır.

\section{Çıkar Çatışması Beyanı}

Çalışma kapsamında herhangi bir kişi ya da kurum ile çıkar çatışması bulunmamaktadır

\section{Kaynaklar}

Board, M. (1996). Simulated Voyages: Using Simulation Technology to Train and License Mariners: National Academies Press.

Bouras, D. (2000). An Investigation into The Feasibility of Introducing A Marine Engine Simulator into the Algerian MET [Maritime Education and Training] System. World Maritime University Dissertations, 76.

Cross, S. J. (2011). Quality MET through Quality Simulator Applications. Paper presented at the International Conference IMLA.

Gan, G., Ma, C. ve Wu, J. (2007). Data Cluster Theory, Algorithms And Applications (Asa-Siam Series On Statistics And Applied Probability),Canada: SIAM Society for Industrial and Applied Mathematics Publishing.

Halkidi, M., Batistakis, Y. \& Vazirgiannis, M. (2001). On Clustering Validation Techniques. Journal of Intelligent Information Systems, 17, 107-145. https://doi.org/10.1023/A:1012801612483

Jain, A. K. (2010). Data Clustering: 50 years beyond K-means. Pattern recognition letters, 31(8), 651-666.

Kanungo, T., Mount, D. M., Netanyahu, N. S., Piatko, C. D., Silverman, R., \& Wu, A. Y. (2002). An Efficient K-Means Clustering Algorithm: Analysis And İmplementation. IEEE Transactions on Pattern Analysis and Machine Intelligence, 24 (7), 881-892. doi: 10.1109/TPAMI.2002.1017616.

MacQueen, J. (1967). Some Methods for Classification and Analysis of Multivariate Observations. Proceedings of the Fifth Berkeley Symposium on Mathematical Statistics and Probabilities, 1, 281-296.

Ostertagová, E., Ostertag, O., \& Kováč, J. (2014). Methodology and Application of the Kruskal-Wallis Test. Applied Mechanics and Materials,

611,

115-120.
https://doi.org/10.4028/www.scientific.net/AM M.611.115

Pakhiraa, K., Bandyopadhyay, S., \& Maulik, U. (2004). Validity Index for Crisp and Fuzzy Clusters. Pattern Recognition, 37 (3), 487-501. https://doi.org/10.1016/j.patcog.2003.06.005

Sendi, Y. (2015). Integrated Maritime Simulation Complex Management, Quality And Training Effectiveness From The Perspective Of Modeling And Simulation In The State Of Florida, USA (A Case Study). University of Central Florida, 2004-2019.

Tekin, B. (2018). Ward, K Ortalamalar Ve İki Adımlı Kümeleme Analizi Yöntemleri İle Finansal Göstergeler Temelinde Hisse Senedi Tercihi. Ballkesir University The Journal of Social Sciences Institute, 21 (40), 401-436.

Wu, K. L. ve Yang, M. S. (2002). Alternative K-means Clustering Algorithms. Pattern recognition, 35(10), 2267-2278.

Url-1

$<$ https://gisis.imo.org/Public/SIM/Default.aspx $>$, erişim tarihi 21.12.2020.

\section{Url-2}

$<$ https://en.wikipedia.org/wiki/Maritime_Univ ersity_of_Szczecin>, erişim tarihi 30.01.2021.

Url-3 <https://www.edumaritime.net/easterneurope/poland/gdynia-maritime-universitygdynia>, erişim tarihi 30.01.2021.

Url-4 <https://cmu-edu.eu/en/>, erişim tarihi 30.01 .2021 .

Url-5 $\quad<$ https://www.bsma.edu.ge/sub7/program/2/index.html $>$, erişim tarihi 30.01 .2021 .

\section{Url-6}

$<$ https://www.denizcilikbilgileri.com/turkiyede -denizcilik-egitimi-veren-tum-fakulteler/>, erişim tarihi 30.01.2021. 